\title{
ESTIMATE ATTRACTION RATE FOR SHOPPING CENTERS
}

\begin{abstract}
In developing countries like Baghdad, it has seen high growth of urbanization accompanied by the high trip rate, which conduces increased vehicle traffic and human traffic. One of the major problems is the increase in traffic congestion of unplanned development of various structures at various locations. Four-step demand models are important in planning and forecasting future demand. Trip generation is an important step when planning urban infrastructure. In this study, three shopping centers (AL Mansour mall, Babylon mall, and al Waha mall) were selected, trip attraction rates were calculated using two approaches (trip rate analysis method, and Regression analysis method). The number of persons entering and exiting the site for every 15-minute interval during peak hours is estimated. This research considers various physical characteristics of shopping centers, gross floor area (GFA), number of employees and the number of stores in the shopping center. From the data analysis, good relations exist between the dependent variable (trip rate) and various independent variables, and the developed trip rate per GFA per $1000 \mathrm{~m} 2$ is 133 person trips and various trip rates are presented through this study.
\end{abstract}

Keywords: Trip Rate; Regression Analysis; Trip attraction; Trip Generation.

Noor Moutaz Asmael ${ }^{1}$

${ }^{I}$ Assist. Prof., Highway and Transportation Department, College of Engineering, Mustansiriyah

University, Baghdad, Iraq.Email: noor_moutaz@uomustansiriyah.edu.iq

Noor Kadhim ${ }^{2}$

${ }^{2}$ Graduate student, Highway and Transportation Department, College of Engineering, Mustansiriyah

University, Baghdad, Iraq.

\section{Introduction}

Travel demand forecasting is central to the design of transportation infrastructure and the creation of policies and regulations for urban planning. The four-step modelling is the most common method used in demand modelling. The first stage of modelling in four-step modelling is to forecast the trip generation (Ortu zar and Willumsen 2011) [1]. Trip generation estimates the number of trips start (production) or end (attraction) in a zone. Trip production represents the trip produced by households in the traffic analysis zone (TAZ), while trip attraction represents trips attracted by land-use activities in TAZ (Escamilla et al., 2016; Sasidhar et al., 2016; Stover and Koepke, 1988) [2-4]. Trip generation is one of the steps in the traditional transport modeling process. Trip generation rates can influence the magnitude of the roadway improvements that are constructed like the amount of land that is required to be dedicated for the road's right-of-way, and calculation of long term maintenance costs of the roadway network.

Many studies have found that the land use types and their activities has a direct influence on trip attraction (Escamilla et al., 2016) [2]. The generation of trips is a necessary step in the planning of transport facilities. Improved accuracy of the generation model is necessary to achieve accurate prediction results. The trip attraction modeling in each determined zone in a city can be carried out by linking the trips derived from the field site survey and specific land use parameters. Globally, there are many studies conducted to determine the rate of attraction of trips to shopping malls, schools, or other land use. Some of these studies are: a study was conducted in Dhanmondi area in Bangladesh by Md Majbah Uddin et. al. [5], they were using the travel rate analysis method for determining the travel attraction rates for shopping centers in Dhaka, they stated that this study would be useful in the design transportation network or the channelization of traffic control around a shopping center. Another study in Uttara Area was conducted by Md. Shamim Al Razib and Faysal Ibna Rahman [6]. The trip attraction rates of the shopping centers at Uttara road were estimated, rates are estimated by using the trip rate analysis method. They concluded that the highest peak hour person Trip Attraction Rate is in Rajlaxmi Complex with 13 person trip/1000 sq.ft/hour on weekend. Because trip attraction volumes are estimated based on land use characteristics and executing of land use-based trip attraction models are severely constrained by the lack of updated land-use data in developing countries, Amila Jayasinghe et al. 2017 [7], introduced a network centrality-based method to estimate the volume of trip attraction in traffic analysis zones. They used explanatory variables as "connectivity", "local integration" and "global integration". This method is an effective tool for developing countries and it does not depend on land use data to estimate trip attraction in the proposed model. In Delaware, a study was conducted by Shinya Kikuchi et al. 2004[8], they computed the attraction of shopping centers in Delaware, a total of 18 sites were being analyzed, and they assessed the patterns of movement of persons and vehicles using two approaches (microscopic and macroscopic). The microscopic approach deals with the trip rate of a mall as an individual center while the macroscopic approach deals with the relation between trip rate and physical features of centers. Joni Arliansyaha, ${ }^{*}$, Yusuf Hartonob 2015 [9] developed trip attraction model with seven independent variables, i.e., population size, number of schools, number of students, number of teachers, areas of school buildings, number of 
offices, and number of houses by applying Radial Basis Function Neural Networks (RBFNN). The neural network model trained to predict trip attraction using seven predictors performs better than the ordinary regression model using the least square approach. Alexandre A. Amavi et al. 2014[10] introduced advanced generation/attraction models considering spatial correlation, and their improvements concerning previous models not considering spatial correlation are analyzed. K. M. RAHMAN1 et al. 2017[11], studied Kaptai road which is an important and busy road in Chittagong to determine the trip generation of adjacent commercial land uses. Trip generation situation was estimated with multiple linear regression models and trip rates of commercial land use. They concluded the weighted average rates of the shopping centers are 9.32 trips/ 1,000 sq. ft./hr. Reigna Jewel Ritz M. MACABABBAD et al. 2009[12] studied trip generation characteristics of the eight government office complexes in Quezon City through site characteristic surveys. Estimates of trip generation rates for this type of land use were obtained for the A.M. and P.M. Peak hours rates were estimated using the gross floor area and the number of employees as independent variables. The number of employees was found to be a better estimator of trip generation than GFA. Khaled Al-Sahili et al. 2018[13] established trip generation rates for the different land-use considering the most appropriate independent variables. It was found that the local trip generation rates were generally different (higher, comparable or lower). This can be attributed to the facts that travel behavior as well as socioeconomic and land use characteristics are different. F. Akter et al. 2016 [14] focused on estimating the trip attraction rate of a mega shopping mall and a school of Dhaka City using a trip rate analysis method. The major Trip rate analysis results found are average peak hour person trip attraction rate 3.91 trips/1000ft2/hour and average peak hour car trip attraction rate is 1.76 trips $/ 10000 \mathrm{ft} 2 /$ hour for Bashundhara City. They indicate the importance of trip rate analysis before constructing any mega structures at Dhaka as new structures will affect the normal trip generation of the surrounding area by attracting a large amount of traffic. A study conducted by Parikh M.S, and Dr. H.R.Varia[15], they were designed to study the generation of trips in the residential urban area. Very few scholars have attempted to build a model of the tripgenerating shopping event for the urban area of India. Uddin et al[5] calculated the attractiveness of shopping malls trip rate in the Dhanmondi area of Dhaka City by using trip rate analysis. They linked the attractiveness of the shopping center as a feature of the physical characteristics of the shopping malls.

In demand modeling, major activity centers of different land-use produce different trip rates, these rates are very important values used in predicting the future attraction of other developments, which in turn is used to predict the need for infrastructures and city transportation facilities. The new development will increase the demand for travel by also increasing the number of vehicles so that it is necessary to know the attractions of this development. The trip attraction is related very strongly to land use characteristics. To accurately plan the need for city transportation facilities and infrastructures, there is a need for an accurate estimate of trip attraction rates. Further trip rates vary from site to site and city to city. Improving the accuracy of the trip model is essential to get a better result of the trip predictions. In such a way, the demand for trips in a given future scenario can be precisely estimated by knowing the explanatory variables in that scenario. Due to limited research about the trip attraction of shopping centers in Baghdad city, and transportation impact studies for new developments are not yet adopted so there is a need to measure trip attraction. The principle goal of this study is to determine the trip generation of shopping center land uses of Baghdad city through fulfilling two objectives;

1 - Identify and quantify the number of trips generated by land use shopping centers

2- To relate the generation of trips concerning land use and the characteristics of the selected sites.

\section{Study Area}

The city of Baghdad is experiencing rapid urbanization and motorization, which in turn gives a dramatic increase in transportation demand, and the supply remains unparalleled with demand. The trip attraction is critical for traffic engineers and planners to consider the impact of new developments such as office complex, shopping center and residential development on current and future infrastructure. Baghdad city which is the capital of the Republic of Iraq; has the largest urban population in Iraq. It is the hub of banking, commerce, and manufacturing in Iraq. The Tigris River is the most important natural characteristic of the city's identity, this divides Baghdad into Karkh and Rusafa. It has an area of 204.2 square kilometers with a population of 8.405 inhabitants (census 2015) [16]. This area type is typified by horizontal expansion, a wide range of land uses, an extensive travel pattern, and shared and priced parking both on/off-street and in structured garages or surface lots. The area is typically an employment destination. It has several sub-malls about 13 shopping malls are currently under construction and has 6 main shopping malls. The big shopping malls already exist are as follows:

- Al Mansour Mall,

- Babylon Mall,

- Baghdad Mall in Al Mansour area,

- Zayouna Mall in Zayouna area,

- Al Nakheel Mall in Palestine Street area,

- Al Waha Mall in Jadriya.

Traffic congestion around shopping malls tends to make people move away from shopping malls to other places to avoid delays, the length of the queue is increasing and patterns of the road network change according to people's accessibility needs and desire to reach their destinations. 


\section{Sample size}

The sample size was based on the ITE guide (2019)[17] which states that a minimum of four sites should be provided to get useful information and conduct analysis. The better reliability of equations when the higher sample size could be reached, ITE claimed that a sample size of at least four should be used for the creation of the regression model. The sample size for developing trip attraction rates or equations is four, according to the ITE manual. The data required about dependent and independent variables must be collected. The selection of independent variables depends on the specific activity of each land use. If the land use is residential land might use dwelling units, while if it's retail land use then the number of employees is used as a variable. In this study, the independent variables include (gross floor area, number of shops and employees). The dependent variable is the total of person trips for each shopping center during peak hours. Estimation of variables for each site was undertaken in terms of how many (surveyors) are needed to calculate the number of people entering and leaving each gate in each shopping center and access of the site and land use. As stated by ITE, the time of counting is selected according to the peak of selected land use, and to the purpose of the study. For the selected sites, the peak periods for the shopping center were selected for the weekend/ weekday in the Pm time. The ITE used a larger interval ( 1 hour) to capture the variation during the whole day (ITE, 2019). This study covers the weekday and weekends and for the evening period from 5 to $8 \mathrm{Pm}$.

\section{Data collection}

People attracted to shopping centers for various purposes like shopping, restaurant, games, and other services. Several people enter and leave the shopping centers were calculated every 15 minutes by surveyors who standing near the entrance and exits of shopping centers to determine the trip attraction rate. The 15minute interval is chosen because the Highway Capacity Manual uses this interval as the base unit for Capacity computation (Kikuchi et al., 2004)[8]. Shopping trips were estimated by visual observation and collecting information about different physical features (i.e. Number of shops, gross floor area, number of an employee). These collected data were processed for the construction of a regression model in SPSS software to determine the rate of travel attraction concerning different physical characteristics.

Three shopping malls in Baghdad city were selected in this study: Al Mansour Mall, Babylon, and Al Waha.

- Al Mansour Mall is a shopping mall located in the Iraqi capital city, Baghdad, in the Mansour district. It is one of the largest shopping complexes in the city of Baghdad, and consists of four floors of an area of 32,000 square meters and contains more than 170 shops, and several brands; clothing stores, electronics stores, and restaurants.

- Babylon Mall is a shopping mall located in Baghdad city, Iraq, in the Mansour district, the complex is built on an area of $4000 \mathrm{~m} 2$ with a height of six floors with a building area of up to $3500 \mathrm{~m} 2$ for each floor. This commercial complex features a heritage market in Baghdad, in addition to a floor for selling children's equipment. It has entertainment and toys for children.

- $\quad \mathrm{Al}$ Waha Mall is one of the commercial centers in Baghdad in the Jadriya area contains many shops, restaurants, games hall, an area of 2500 square meters and the number of shops about 43 stores The details of selected shopping centers are given in Table 1:

Table 1. Characteristics of Shopping Centers

\begin{tabular}{ccccc}
\hline $\begin{array}{c}\text { Shopping } \\
\text { center }\end{array}$ & $\begin{array}{c}\text { Number } \\
\text { of Gates }\end{array}$ & $\begin{array}{c}\text { Number } \\
\text { of Shops }\end{array}$ & $\begin{array}{c}\text { Number of } \\
\text { Employees }\end{array}$ & $\begin{array}{c}\text { Total } \\
\text { floor } \\
\text { Space }\end{array}$ \\
\hline $\begin{array}{c}\text { Al- } \\
\text { Mansour }\end{array}$ & 2 & 170 & 950 & 32000 \\
Mall & & & & $\mathrm{m}^{2}$ \\
$\begin{array}{c}\text { Babylon } \\
\text { Mall }\end{array}$ & 1 & 154 & 650 & 4000 \\
Al-waha & 3 & 43 & 250 & 2500 \\
Mall & & & & $\mathrm{m}^{2}$ \\
\hline
\end{tabular}

The location of three shopping centers is marked on the map in Figure 1.

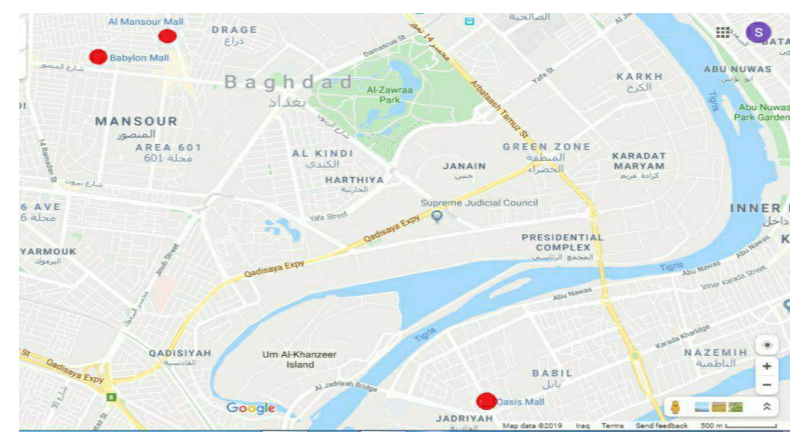

Fig. 1 Selected Shopping Centers

The following survey results are shown in Figure 2, from observing the Figure below; the peak hour for shopping centers is from 7 to $8 \mathrm{pm}$. 

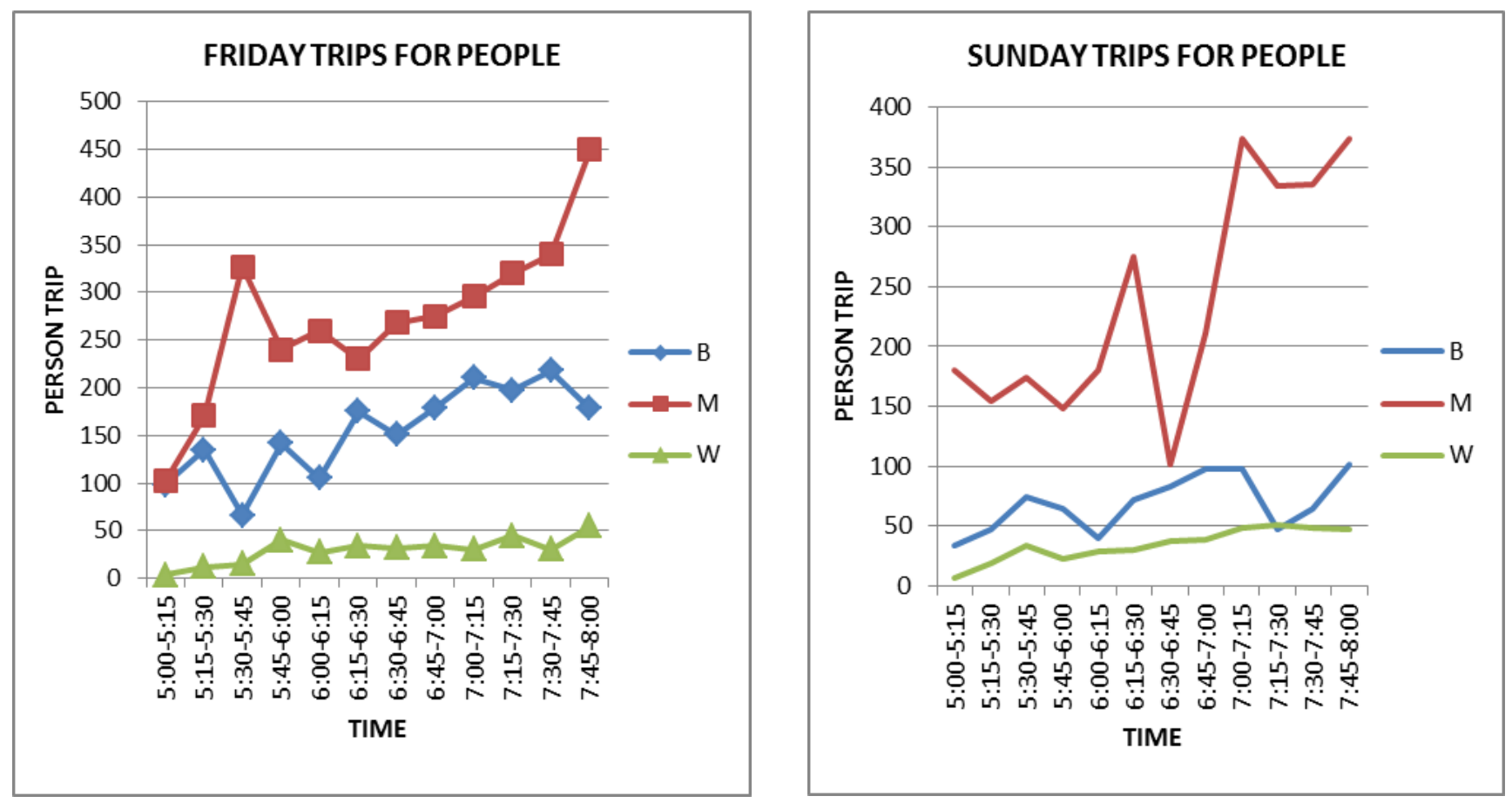

Fig. 2. Variation of Person Trips for Weekday and Weekend

\section{Methodology}

Two methods (Regression analysis and Trip rate) were used to estimate trip attraction rate. The dependent variables used for analysis depend on the selected land use, in our case, for shopping centers, the number of trips was chosen as the dependent variable. The definition of some of the terms used is defined below:

-Daily Customer - a person who visits a building to conduct personal business at any time during a single day.

- Employee - a full-time, part-time, or per diem/contract worker. They represent all the persons employed at the site, not just persons who appear at the time of data collected.

- Gross Floor Area (GFA)- refers to the total area (expressed in square meters), Occupied area refers to GFA within the facility which is currently being utilized. If the ground-floor area or part thereof is not enclosed within the main exterior walls, this floor area is considered to be part of the overall GFA of the building. GFA used as an independent variable for trip generation calculation, For calculation, the floor area of all parking garages within the building should not be included in the GFA of the entire building.

Average Rate (Average Trip Rate) - the weighted average number of vehicle or person trips entering or exiting a development site per one unit of the Independent Variable. It is estimated by dividing the sum of all trips for all data point sites contributing by the sum of all independent variable units for all data point sites contributing.

The trip attracted to shopping centers was obtained by counting the number of people entering and leaving the shopping center every 15 minutes from 5 to $8 \mathrm{pm}$. Two surveyors needed near the entrance and exit of shopping centers for collecting trip data. Visual observation was used to count the trip. Data were obtained basis on a weekday and weekend. There was a variation in trip data which, the basis on the day of the week, time of the day. The independent variable data of characteristics shopping centers were collected and statistical analysis was carried out to estimate the rate of attraction of the trip. The trip attraction rate was estimated by the following equations:

1. Trip attraction rate (Trips/1000 sq.m2) $=$ Total person trip /(GFA/1000)

2. Trip attraction rate (Trips/shop) $=$ Total person trip/total number of shops

3. Trip attraction rate (Trips/employees) $=$ Total person trip/ number of employees

Maximum hourly travel data for each shopping center was considered the highest hourly data used in the analysis. The sum of every four consecutive intervals of peak hour was then used for the calculation of the peak hour trip data. The following Figure 3 shows the methodology of the study. This was done for both weekday data and weekend data. Linear Regression Model is used for analyzing the collected data. 


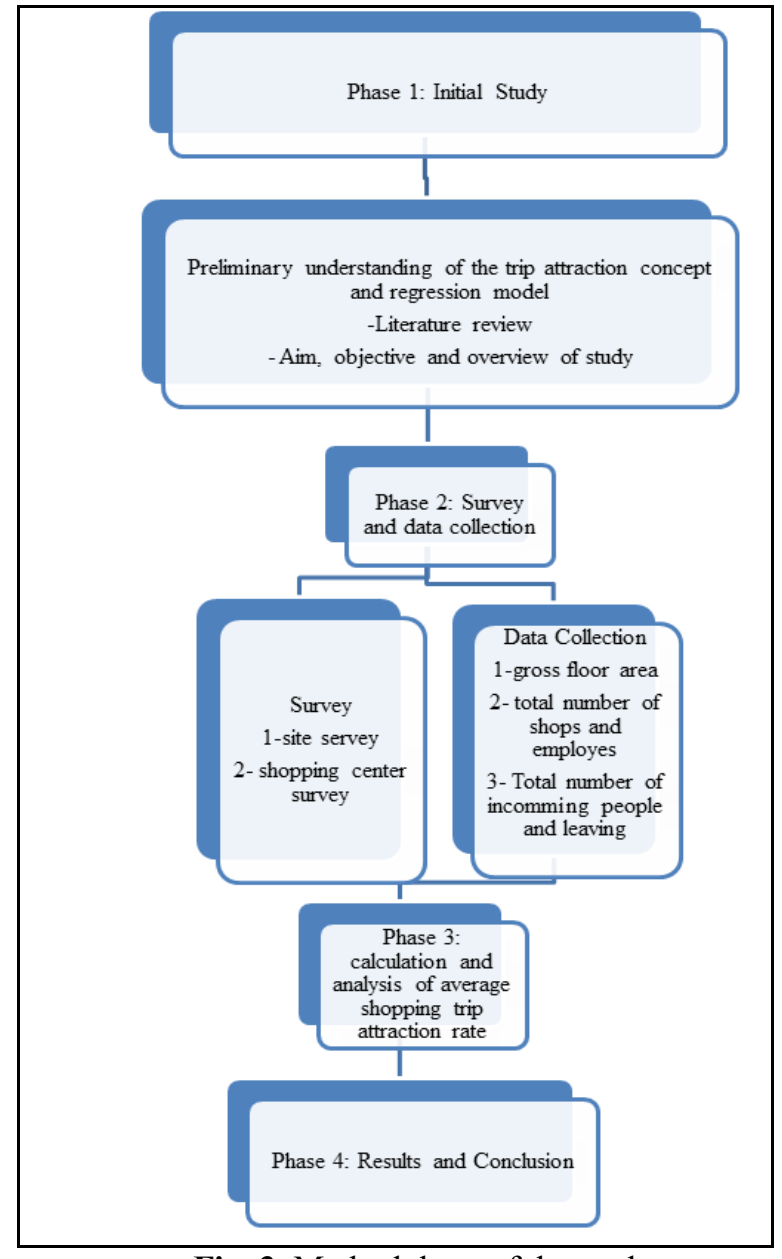

Fig. 3. Methodology of the study

From the analysis of count data the following summary data of average trip for three days for both weekend and weekday are shown in Table 2.

Table 2. Average Trips of all Shopping Centers

\begin{tabular}{|c|c|c|c|}
\hline \multirow{2}{*}{$\begin{array}{c}\text { Shopping } \\
\text { Centers }\end{array}$} & \multirow{2}{*}{ Code } & \multicolumn{2}{|c|}{ Average Trip } \\
\cline { 3 - 4 } & $\begin{array}{c}\text { Peak } \\
\text { (weekend) }\end{array}$ & $\begin{array}{c}\text { Peak } \\
\text { (weekday) }\end{array}$ \\
\hline Babylon Mall & $\mathrm{B}$ & 1760 & 1096.75 \\
\hline $\begin{array}{c}\text { Al-Mansour } \\
\text { Mall }\end{array}$ & $\mathrm{M}$ & 2945 & 2968 \\
\hline Al-Waha Mall & $\mathrm{W}$ & 407 & 350.25 \\
\hline
\end{tabular}

From this analysis, it was observed that most shopping centers had peak hours from 7,00 to $8,00 \mathrm{pm}$. In this study, data were collected between $5,00 \mathrm{pm}$ to 8,00 $\mathrm{pm}$. The highest hourly data is taken as the average hourly travel rates for each shopping center. This methodology is being pursued for both weekday and weekend research, it is clearly shown that shopping centers are attracting more weekday trips.

Building a statistical relationship (statistical equation) between two quantitative variables, dependent and independent variables using regression analysis. A simple linear regression model generated between variables and the dependent variable. This relationship can be used to estimate the value of the dependent variable when knowing the value of the independent variable. The value of y represents the dependent variable and the value of $\mathrm{x}$ represents the independent variable. The Table 3 shows a descriptive statistical analysis of the trip rate for all shopping centers per (total area, number of workers and shops) and the following regression models were developed and shown in Table 4.

Table 3. Descriptive statistical of Average Trip

\begin{tabular}{|c|c|c|c|c|c|}
\hline \multicolumn{2}{|c|}{$\begin{array}{l}\text { Average Trip per } \\
\text { GFA }\end{array}$} & \multicolumn{2}{|c|}{$\begin{array}{l}\text { Average Trip } \\
\text { Rate per Number } \\
\text { of Employees }\end{array}$} & \multicolumn{2}{|c|}{$\begin{array}{l}\text { Average Trip } \\
\text { rate per Number } \\
\text { of shops }\end{array}$} \\
\hline Mean & 133 & Mean & 2.76 & Mean & 14 \\
\hline $\begin{array}{l}\text { Standar } \\
\text { d Error }\end{array}$ & $\begin{array}{l}35.384 \\
38\end{array}$ & & $\begin{array}{l}0.4401 \\
03\end{array}$ & & $\begin{array}{l}3.9292 \\
07\end{array}$ \\
\hline Median & $\begin{array}{l}127.41 \\
56\end{array}$ & Median & $\begin{array}{l}2.7076 \\
92\end{array}$ & Median & $\begin{array}{l}13.394 \\
32\end{array}$ \\
\hline $\begin{array}{l}\text { Standar } \\
\mathrm{d} \\
\text { Deviati } \\
\text { on } \\
\end{array}$ & $\begin{array}{l}50.041 \\
06\end{array}$ & $\begin{array}{l}\text { Standar } \\
\mathrm{d} \\
\text { Deviati } \\
\text { on }\end{array}$ & & $\begin{array}{l}\text { Standar } \\
\mathrm{d} \\
\text { Deviati } \\
\text { on }\end{array}$ & $\begin{array}{l}5.5567 \\
37\end{array}$ \\
\hline $\begin{array}{l}\text { Sample } \\
\text { Varian } \\
\text { ce }\end{array}$ & $\begin{array}{l}2504.1 \\
08\end{array}$ & $\begin{array}{l}\text { Sample } \\
\text { Varian } \\
\text { ce }\end{array}$ & $\begin{array}{l}0.5810 \\
71\end{array}$ & $\begin{array}{l}\text { Sample } \\
\text { Varian } \\
\text { ce }\end{array}$ & $\begin{array}{l}30.877 \\
33\end{array}$ \\
\hline Range & $\begin{array}{l}70.768 \\
75 \\
\end{array}$ & Range & 1.472 & Range & $\begin{array}{l}7.8584 \\
13 \\
\end{array}$ \\
\hline $\begin{array}{l}\text { Minim } \\
\text { um }\end{array}$ & $\begin{array}{l}92.031 \\
25 \\
\end{array}$ & $\begin{array}{l}\text { Minim } \\
\text { um }\end{array}$ & 1.628 & Minim & $\begin{array}{l}9.4651 \\
16 \\
\end{array}$ \\
\hline $\begin{array}{l}\text { Maxim } \\
\text { um }\end{array}$ & 162.8 & $\begin{array}{l}\text { Maxim } \\
\text { um }\end{array}$ & 3.1 & $\begin{array}{l}\text { Maxim } \\
\text { um }\end{array}$ & $\begin{array}{l}17.323 \\
53\end{array}$ \\
\hline Sum & $\begin{array}{l}254.83 \\
13\end{array}$ & Sum & $\begin{array}{l}7.4356 \\
92\end{array}$ & Sum & $\begin{array}{l}26.788 \\
65\end{array}$ \\
\hline
\end{tabular}

Statistical models are generated to correlate 1 hour average trip with physical characteristics (GFA, number of stores and employees) of shopping centers. For the shopping centers, in the regression model, 1-hour trip attractions are taken as the dependent variable and physical features are taken as independent variables. This methodology is being pursued for both weekday and weekend research 
Table 4. Developed statistical Models

\begin{tabular}{|c|c|c|c|c|c|}
\hline \multicolumn{6}{|c|}{ With the independent variable of gross floor area (GFA) } \\
\hline \multicolumn{6}{|l|}{ For weekday } \\
\hline & Coefficients & Standard Error & t Stat & P-value & $\mathrm{R}^{2}$ \\
\hline Intercept & 458.8027 & 353.336 & 1.298488 & 0.417787 & 0.945654 \\
\hline GFA & 78.92446 & 18.92042 & 4.171391 & 0.149789 & \\
\hline \multicolumn{6}{|l|}{ For Weekend } \\
\hline & Coefficients & Standard Error & t Stat & P-value & $\mathrm{R}^{2}$ \\
\hline Intercept & 851.1779354 & 705.0366397 & 1.207282 & 0.440391 & 0.755998632 \\
\hline GFA & 66.45366737 & 37.75327044 & 1.76021 & 0.32890579 & \\
\hline \multicolumn{6}{|c|}{ With the independent variable of the number of employees } \\
\hline \multicolumn{6}{|l|}{ For Weekday } \\
\hline & Coefficients & Standard Error & t Stat & $P$-value & $\mathrm{R}^{2}$ \\
\hline Intercept & -772 & 834.9715298 & -0.92458 & 0.5249341 & 0.89776945 \\
\hline no.of employees & 3.638378378 & 1.227766556 & 2.963412 & 0.2071879 & \\
\hline \multicolumn{6}{|l|}{ For Weekend } \\
\hline & Coefficients & Standard Error & t Stat & $P$-value & $\mathrm{R}^{2}$ \\
\hline Intercept & -523.75 & 108.4006504 & -4.83161 & 0.1299268 & 0.998056988 \\
\hline no.of employees & 3.612567568 & 0.159395486 & 22.66418 & 0.028071 & \\
\hline \multicolumn{6}{|c|}{ With the independent variable of the number of shops } \\
\hline \multicolumn{6}{|l|}{ For Weekday } \\
\hline & Coefficients & Standard Error & t Stat & $P$-value & $\mathrm{R}^{2}$ \\
\hline Intercept & -425.832814 & 1591.551028 & -0.26756 & 0.8335655 & 0.632941791 \\
\hline no.of shops & 15.51089493 & 11.81197287 & 1.31315 & 0.4143363 & \\
\hline \multicolumn{6}{|l|}{ For Weekend } \\
\hline & Coefficients & Standard Error & t Stat & $P$-value & $\mathrm{R}^{2}$ \\
\hline Intercept & -390.441615 & 893.3721105 & -0.4370425 & 0.7376958 & 0.8695834 \\
\hline No.of shops & 17.1207761 & 6.630316557 & 2.58219589 & 0.2352195 & \\
\hline
\end{tabular}

\section{Trips estimated using Trip Rate Method}

Accordingly, the most common and accepted methodology used to calculate forecasted trips was based on the rate 1990[18]. Another method of trip rate was used. Average Rate (Average Trip Rate) equals the weighted average number of vehicle or person trips entering or exiting a development site per one unit of the Independent Variable. It is estimated by dividing the sum of all trips for all data point sites contributing by the sum of all independent variable units for all data point sites contributing, it is clearly shown that shopping centers are attracting more weekday trips. The following Figures from 4-6 shown the average trip rate for different site characteristics.

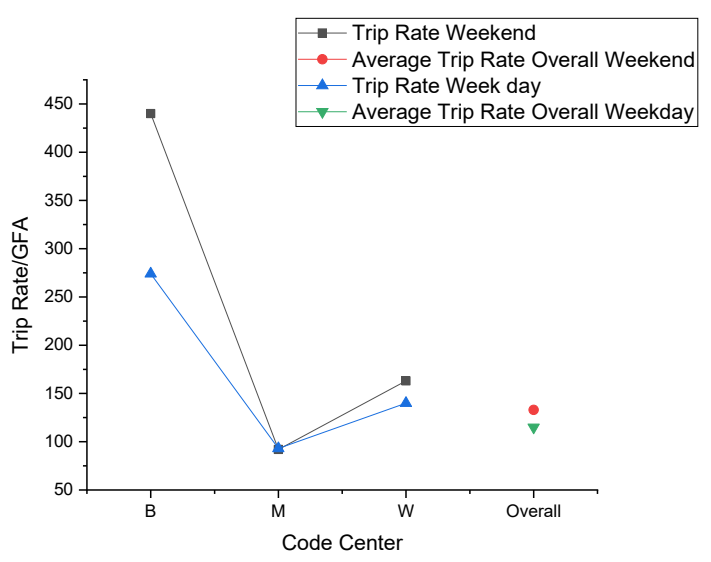

Fig. 4. Trip Rate (Person/GFA) 


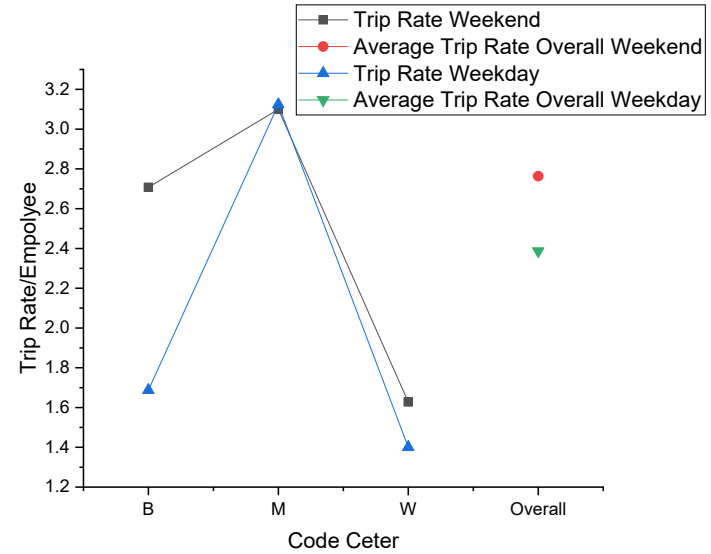

Fig. 5. Trip Rate (Person/ employees/hr)

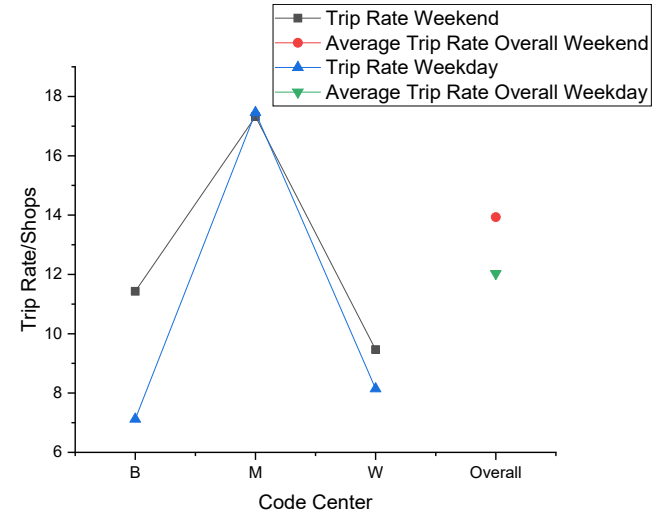

From Figure 4, the highest peak hour trip attraction rate is in Babylon mall in weekend 440 person/ 1000 $\mathrm{m} 2 / \mathrm{hr}$, Babylon mall attracted highest person trips per $1000 \mathrm{~m} 2$ area during peak hour because it is a popular shopping mall of branded clothing. Al_Mansour mall has the lowest peak hour trip attraction rates 92.03124 person trip/1000m $2 /$ hour on weekend. Figure 5 represents the variation in peak hour person trip attraction rate (person/employee/hour) of three shopping centers. AL Mansour mall has the highest trip attraction rate 312.4211 person/employee/hr in weekday and lowest trip attraction rate in Al_waha mall 140.1 person /employee/hr in weekday. From Figure 6, Al_ Mansour mall has made the highest trip attraction rate $17.45882 \mathrm{person} / \mathrm{shop} / \mathrm{hr}$ in weekday and lowest trip attraction rate in Babylon 7.121753 person/shop/hr in weekday. Table 5 shows trip rate values for the three shopping centers.

Fig. 6. Trip Rate (Person/shop/hr)

Table 5. Trip Rate per hour

\begin{tabular}{|l|c|c|c|c|c|c|}
\hline $\begin{array}{l}\text { Code } \\
\text { Center }\end{array}$ & \multicolumn{3}{|l|}{$\begin{array}{l}\text { Peak Person Trip Rate } \\
\text { (Trip/Shop/hr) }\end{array}$} & \multicolumn{2}{l|}{$\begin{array}{l}\text { Peak Person Trip Rate } \\
\text { (Trip/Employee/hr) }\end{array}$} & \multicolumn{2}{l|}{$\begin{array}{l}\text { Peak Person Trip Rate } \\
\text { (Trip/1000m } / \text { hr) }\end{array}$} \\
\hline & Weekend & Weekday & Weekend & Weekday & Weekend & Weekday \\
\hline B & 11.42857 & 7.121753 & 2.707692 & 1.68738 & 440 & 274.1875 \\
\hline M & 17.32353 & 17.45882 & 3.1 & 3.124211 & 92.03125 & 92.75 \\
\hline W & 9.465116 & 8.145349 & 1.628 & 1.401 & 162.8 & 140.1 \\
\hline $\begin{array}{l}\text { Average } \\
\text { Trip }\end{array}$ & 14 & 12 & 2.76 & 2.38 & 133 & 115 \\
\hline
\end{tabular}

\section{Model Validation}

Verification of existing models and rates is tested based on random samples: the sample was chosen for the study of land use to estimate the demand for shopping centers and to make inferences on the variations between the observations and the model estimation. If the predicted values of the models match or are similar to the observed values, the models may be considered confirmed. For this study and according to the scale of the sample examined. An average of $25 \%$ of the difference is acceptable. Al- Nakheel Mall was selected to verify the models and rates. For the regression analysis, the average difference is more than $25 \%$, while for the rate method the average difference is $10 \%$ which is within acceptable limits. It can be concluded that the average trip rate method is more accurate and recommended for future forecasting.

\section{Conclusion}

Trip attraction rate is a key step in the planning of transport facilities and is important for all road networks and for channeling of traffic control around the shopping center. Trip Rate is useful to know the number of people entering an area at a specific time that is very useful for planning and monitoring traffic in that area. In this study, the trip attraction rate of the shopping center was 
calculated, these trips showing a great impact on the transport network. Trip attraction rate determined by considering different physical characteristics of shopping centers. Each model and data should be useful in determining the effect of traffic around a new shopping center and the impact of traffic volumes. In this study regression models were used to determine attractions of shopping centers. Six models developed one is a function of gross floor area $/ 1000 \mathrm{~m} 2 / \mathrm{hr}$, second for several shops in the shopping center and the number of employees, all these for each weekday and weekend period. It is shown from the results that the GFA and number of employees are a good indicator to estimate trip rate. Also, trip rate method gives more accurate results than regression method. The developed trip attraction rate of this study is 133 trip person per GFA per $1000 \mathrm{~m} 2$, this value can be used to predict and develop trip attraction of new shopping centers in Baghdad city; it will be very useful and might help inaccurate prediction of trip rates and also planning of transportation facilities in Baghdad city.

\section{Acknowledgement}

Authors want to thank the highway and transportation department in the College of Engineering at Al Mustansiriyah university for its contribution in supporting this research and assisting in its implementation

\section{References}

Akter, F, M S Chowdhury2 A Alam, and M M Rahman. "ESTIMATION OF TRIP ATTRACTION RATE OF MEGA SHOPPING MALL AND SCHOOL IN DHAKA CITY."

Al-Sahili, Khaled, Sameer Abu Eisheh, and Fawz Kobari. 2018. "Estimation of New Development Trip Impacts through Trip Generation Rates for Major Land Uses in Palestine." Jordan Journal of Civil Engineering 12(4).

Amavia, Alexandre A et al. 2014. "Advanced Trip Generation/Attraction Models." Procedia-Social and Behavioral Sciences 160: 430-39.

Arliansyah, Joni, and Yusuf Hartono. 2015. "Trip Attraction Model Using Radial Basis Function Neural Networks." Procedia Engineering 125: 445-51.

Buttke, Carol H. 1990. "Guidelines for Using Trip Generation Rates or Equations." ITE JOURNAL-INSTITUTE OF TRANSPORTATION ENGINEERS 60(8): 14-16.

de Dios Ortúzar, Juan, and Luis G Willumsen. 2011. Modelling Transport. John wiley \& sons.

Escamilla, Jorge Montejano, Camilo Caudillo Cos, and Jose Silván Cárdenas. 2016. “Contesting Mexico City’s Alleged Polycentric Condition through a CentralityMixed Land-Use Composite Index." Urban Studies 53(11): 2380-96.

ITE. 2019. Parking Generation Manual. USA; Washington, DC. No. IR-034D.

Jayasinghe, Amila, Kazushi Sano, and Kasemsri Rattanaporn. 2017. "Application for Developing Countries: Estimating Trip Attraction in Urban Zones Based on Centrality." Journal of Traffic and Transportation Engineering (English Edition) 4(5): 464-76.

Kikuchi, Shinya, Marian Felsen, Sharat Mangalpally, and Anuj Gupta. 2004. "Trip Attraction Rates of Shopping Centers in Northern New Castle County, Delaware."

Macababbad, Reigna Jewel Ritz, Jose Regin Regidor, and Dean Bartolome. 2009. "A Study on the Local Trip Generation Characteristics of Government Office Land Use." In Proceedings of the Eastern Asia Society for Transportation Studies Vol. 7 (The 8th International Conference of Eastern Asia Society for Transportation Studies, 2009), Eastern Asia Society for Transportation Studies, 85

Organization, Central statistical. 2015. Central Statistical Organization. Iraq.

Parikh, M, and H Varia. 2016. "A Review on Developing Shopping Trip Generation Model in Residential Area of Ahmedabad City-a Case Study of Gurukul Area." International Journal of Engineering Development and Research 4(2): 574-84.

RAHMAN, K M, N A HASHI, and M S AZOM. "Determining Trip Generation of Commercial Land Use of Kaptai Road, Chittagong, Bangladesh.”

Al Razib, Md Shamim, and Faysal Ibna Rahman. 2017. "Determination of Trip Attraction Rates of Shopping Centers in Uttara Area, Dhaka." American Journal of Management Science and Engineering 2(5): 150-55.

Sasidhar, Karuturi, Yeluri Vineeth, and S S V Subbarao. 2016. "Trip Attraction Rates of Commercial Land Use." Indian Journal of Science and Technology 9.

Stover, Vergil G, and Frank J Koepke. 1988. "Transportation and Land Development."

Uddin, Majbah et al. 2012. "A Comprehensive Study on Trip Attraction Rates of Shopping Centers in Dhanmondi Area." International Journal of Civil \& Environmental Engineering 12(4): 12-16. 